\title{
Towards quantitative biochemistry: research and reports in biochemistry
}

This article was published in the following Dove Press journal:

Research and Reports in Biochemistry

6 May 201I

Number of times this article has been viewed

\section{Nikolay V Dokholyan \\ Department of Biochemistry and Biophysics, University of North Carolina, School of Medicine, Chapel Hill, NC, USA}

Since the mid twentieth century the field of biochemistry has evolved significantly (Figure 1). Advances made in the fields of structural, chemical, and systems biology, physics, and computation have shaped the new field of biochemistry such that the emphasis became the cellular-wide view of molecular life at the atomic scale. The principal paradigm in the field shifted from focusing on a single or a few biological molecules to focusing on their cellular- and intracellular-wide networks. This shift has resulted in more interdisciplinary approaches to biochemical research, which nowadays combines techniques and strategies from a broad range of fields. The evolution of the field of biochemistry resulted in closer connections to other fields, such as medicinal chemistry, physiology, and medicine. Biochemistry is also one of the central components of the emerging translational medicine paradigm.

Over the years biochemistry has evolved from a descriptive to a quantitative field, driven by advances in computational approaches, instrumentation, microfluidics, nanotechnology, among other fields. Therefore, there is a need for a platform for dissemination of new quantitative biochemistry research to the scientific community across disciplines. In this new journal Research and Reports in Biochemistry we welcome new and exciting research in the field of biochemistry. We plan to publish a broad range of papers that include original research, reviews, hypotheses, and notes. Welcome to Research and Reports in Biochemistry.

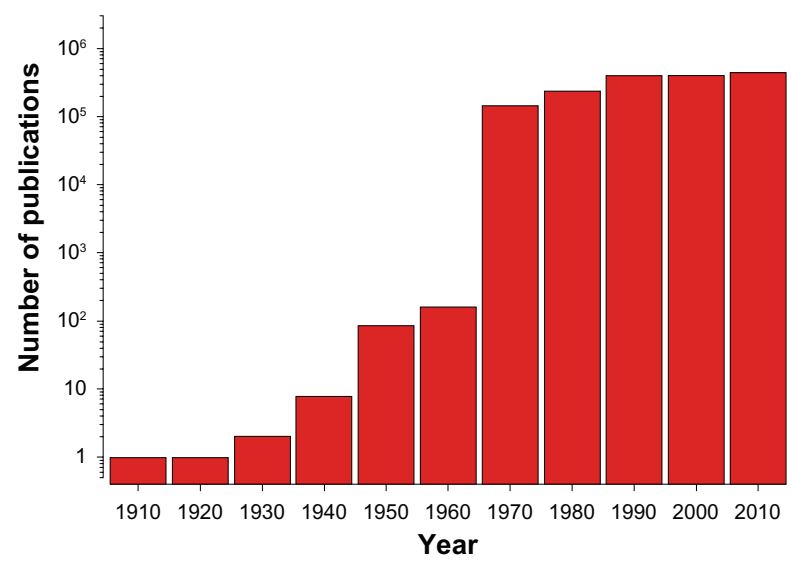

Figure I Semi-logarithmic plot of number of papers published in the field of biochemistry as a function of time. The data is obtained from the ISI Web of Knowledge using keyword Biochemistry.
Correspondence: Nikolay V Dokholyan I20 Mason Farm Rd., Suite 3097,

Chapel Hill NC 27599-7260, USA

$\mathrm{Tel}+19198432513$

$\mathrm{Fax}+19199662852$

Email dokh@unc.edu submit your manuscript | www.dovepress.com

Dovepress

DOI: 10.2147/RRBC.S19537
Research and Reports in Biochemistry 201 I:I I-2

(C) 20II Dokholyan, publisher and licensee Dove Medical Press Ltd. This is an Open Access article which permits unrestricted noncommercial use, provided the original work is properly cited. 


\section{Publish your work in this journal}

Research and Reports in Biochemistry is an international, peer-reviewed open access journal publishing original research, reports, reviews and commentaries on all areas of biochemistry. The manuscript management system is completely online and includes a very quick and fair

peer-review system. Visit http://www.dovepress.com/testimonials.php to read real quotes from published authors. 